\title{
Citizen participation at the level of local rural communities - tentative analysis
}

\author{
"Coming together is the beginning; \\ keeping together is progress, \\ working together is success."
}

(Henry Ford)

\begin{abstract}
Citizen participation is an important element of contemporary democracy. It is considered a panacea to the declining participation of citizens in political and public life. People may decide to participate for various reasons. It is important that participation promotes the development of local democracy, for instance, by strengthening bottom-up civic initiatives; participation stimulates integration of local communities through joint activities. It is also an efficient tool to solve certain problems, since opinions of all parties concerned can be heard, local conflicts mitigated and compromise reached.

This article attempts to analyze citizen participation based on the example of a specific social group, namely the rural local community. The article concentrates on various theoretical views on the issue. The main goal of the article is to answer a question about the form of local rural communities participation, and it presents examples of instruments which help community members to implement their activity and express civic attitudes.
\end{abstract}

Key words: citizen participation, citizen public activity, local community

\section{Introduction}

Citizing itizen participation is an important element of contemporary democracy, significance of which has been growing since the end of the $20^{\text {th }} \mathrm{c}$. It is considered a panacea to the declining participation of citizens in political and public life (Komito, 2005, pp. 39-48). The main categories of participation include: citizen public activity, engagement of citizens in decision making by public authorities, participation in elections, and mandatory participation (Kaźmierczak, 2011, pp. 83-99).

Participation is understood as the involvement of citizens in social life (public, political) (Roberts, 2008). In the civic context, participation can be defined as the involvement of citizens in community-based activity with the aim of common good. It is worth distinguishing social and community participation (horizontal) and citizen participation (verti$\mathrm{cal}$ ). The vertical participation applies to the relationship between the government and citizens, whereas the horizontal participation is primarily the cooperation between various groups and individuals to attain common goals (e.g. neighbors wish to landscape their yard or various organizations dealing with people with disabilities join their forces working towards common goal) (Brodie, Cowling, Nissen, Ellis Paine, Jachum, Warburton, 2009). 
Participation is open to everyone! However, it is important to know how this can be actually done. Citizen participation, which in principle involves citizens and local governments, also engages non-governmental organizations. Thus, the latter initiate activities and mediate between the two other main players. This model improves communication and allows for better organization of the process (Creighton, 2005).

This article attempts to analyze citizen participation based on the example of a specific social group, namely the rural local community. The article concentrates on various theoretical views on the issue. The main goal of the article is to answer a question about the form of local rural communities participation, and it presents examples of instruments which help community members to implement their activity and express civic attitudes. ${ }^{1}$

\section{Participation and local community - preliminary definition}

Participation is not an easy process. It necessitates the will of parties involved, knowledge, transparency, honest approach, consensus and awareness of possible benefits for participants. Participation can be best observed at the local level, since it is the level of operation closest to local communities (education, social care, healthcare, culture, recreation etc.). Citizen participation has been known for many years in well-established democratic systems. It strengthens those systems, especially on the local level. Today, we have a number of ways of influencing the public decision making. In the West, the process is regulated by the law, customs and tradition. Although Poland has also adopted legal regulations, as well as relevant tools and instruments, they are rarely used. This applies in particular to the central administration which infrequently resorts to public consultation, and treats it rather as a part of the formal process. New tools, which started to be used in the management of public affairs, open space for citizens and organizations to influence the decision-making process. People can either support an initiative, or block or modify it.

The participation of citizens, through provision of information, consultations, as well as co-deciding, can be achieved using various tools. While selecting those tools, we need to take into consideration the goal and the function of participation (IAP2 Spectrum of Public Participation...). Before citizens gain any possibility of influencing the decisionmaking process, they need to be well informed. Provision of information aims at furnishing citizens with knowledge about planned or implemented activities. Consultation is nothing more than giving citizens a possibility to expressing their opinion about activities planned. People who participate in consultation are requested to share their comments and opinions on a specific matter. Although the voice of citizens is examined, there is no guarantee that it will be reflected in actual actions taken. At the moment, partially due to regulations, it is one of the most popular forms of citizen participation in Poland. The main goal of public consultation should be to seek solutions facilitating decision making for the benefit of the community. While considering public consultations as a process promoting dialogue with and involvement of citizens in the community-based decision making in Poland, an under-

${ }^{1}$ More about citizen participation, as well as other techniques, see J. Elliott, S. Heesterbeek, C. J. Lukensmeyer, N. Slocum (2005), Participatory Methods Toolkit. A practitioners manual, King Baudouin Foundation, https://participationobywatelska.pl/wp-content/uploads/2015/07/PUB_1540_ Participatoty_toolkit_New_edition.pdf, 23 March 2019. 
lying document is the Constitution of the Republic of Poland in general, and its Article 4 in particular. The article states that the supreme power in the Republic of Poland is exercised by the people and actually the people exercise it directly or through their elected representatives. Moreover, Articles 54, 61 and 74 set standards for the access to information about the activity of public bodies. Co-decision is the highest degree of citizen participation. It is possible due to partnership relations between the authority and citizens, in which certain competences and responsibilities are vested in citizens regarding certain activities and decisions. Thus, citizens gain real influence on the planning of those activities.

Participation of citizens in adopting laws and making decisions can be voluntary or mandatory. In Poland, apart from the provisions of the Constitution, citizens are encouraged (or obligated) to participate as prescribed by various laws and regulations, in particular by the "Public Dialogue Rules"2 adopted by the Government.

Fig. 1 Participation chart

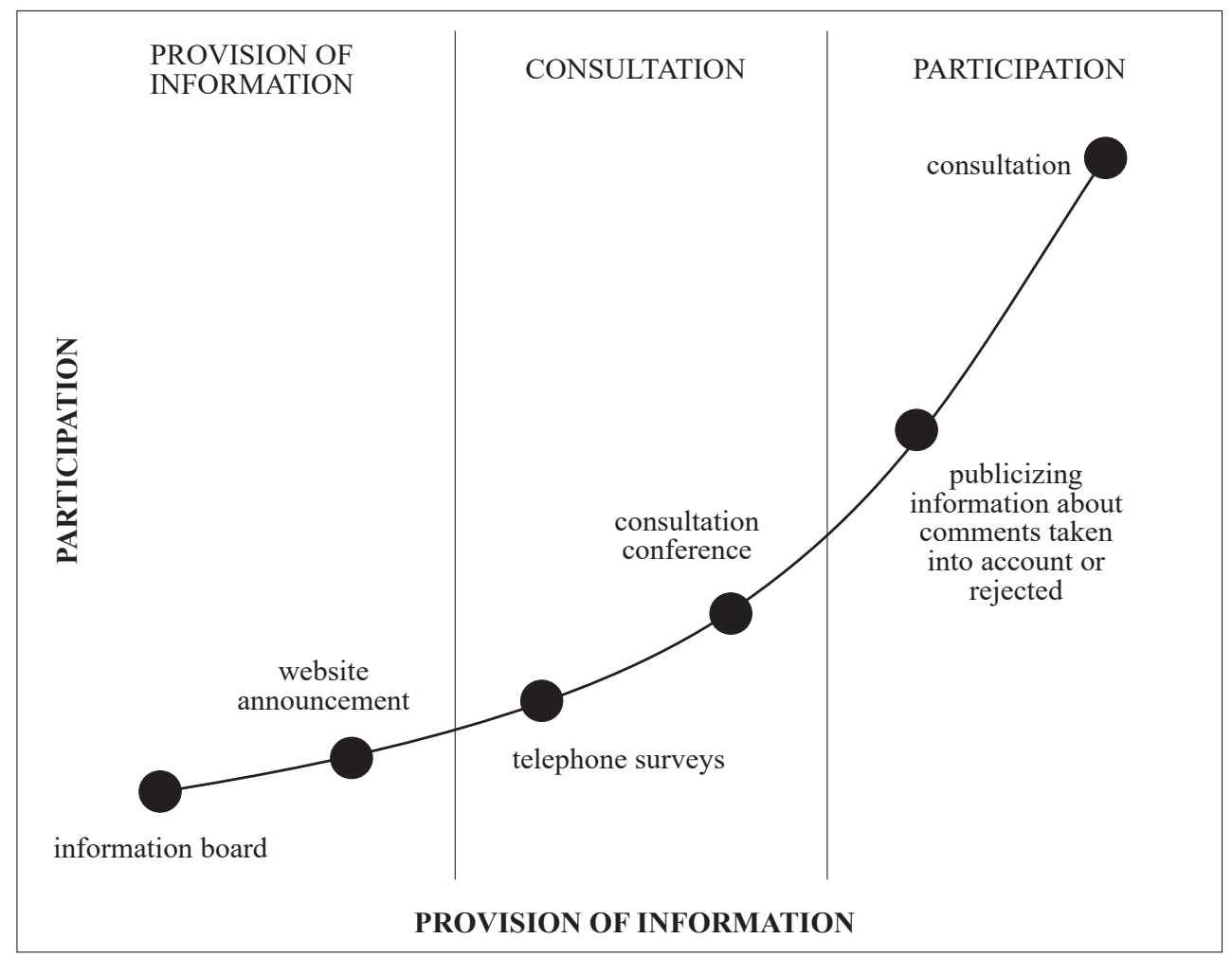

Source: Partycypacja społeczna w praktyce, Warsaw 2009, https://partycypacjaobywatelska.pl/wpcontent/ uploads/2015/08/Broszura_Konsultatywa1.pdf,_15.03.2019.

${ }^{2}$ The Public Dialogue Rules were developed by the SLD-UP-PSL coalition government to define framework for the public dialogue and methods for cooperation with social partners based on various laws in different areas of public life. The government considered advisable to use rules specified in the document as guidelines for consecutive governments, provided those governments express their will to apply those rules, see also: http://ofop.eu/sites/ofop.eu/files/biblioteka-pliki/zasady_dialogu_spolecznego_0.pdf, 08.03.2019. 
People may decide to participate for various reasons. It is important that participation promotes the development of local democracy, for instance, by strengthening bottom-up civic initiatives; participation stimulates integration of local communities through joint activities. It is also an efficient tool to solve certain problems, since opinions of all parties concerned can be heard, local conflicts mitigated and compromise reached.

The local community (Latin. localis - specific location in wider space) is a group of people occupying a specific limited territory. It may include a parish, village, and a settlement characterized by strong community ties resulting from common needs and interests, as well as the sense of identity and belonging to a specific place.

According to the definition by Paweł Starosta, we may conclude that the local community involves three aspects: spatial (territorial), social (relationship networks, ties) and psychosocial (local identity). While developing his definition, Starosta concluded that the local community is: “... a type of a geographically based social and spatial structure comprising people living in a specific territory within a system of links used to solve local problems and ensure mental identification of people and the place of their existence" (Starosta, 1995, pp. 30-32).

Bruce Lewenstein believes that the "Local community understood as linked neighborhoods that use local resources to implement a number of important economic (services), social (identity), and political (management) functions. The area of a community is delimited by personal and associative relations [...] and frequently expands beyond administrative boundaries of a local system" (Lewenstein, 2006, p. 244).

The local community is not identical to groupings found in large urban areas. Such groupings usually have formal structures, numerous informal contacts, whereas individuals are engaged in short-term relations. Relations in local communities translate into durable connections between family members, neighbors, as well as personal and institutional links. People and their creativity are crucial for the process of local community formation. The major task of local community organizers is to stimulate such creativity.

The local community has a relatively permanent structure and several distinct functions. Firstly, it provides housing which guarantees relevant conditions to live, including social housing for the less fortunate members of the community. Secondly, it is responsible for self-governing in terms of election and control over local authorities, decision making regarding issues important for the community, and exercising the management of common assets. Thirdly, the local community organizes everyday life; thus, it is difficult to refer to people living in dormitory housing estates as local communities. The identity of a local community is based on common tradition, culture, religion, space and ownership. Yet another function is related to meeting of basic needs, such as consumption, healthcare, education and social care. Through its socializing function, the local community supports and promotes important social values. It can teach social roles and shape civic and social attitudes. Finally, the cultural function is implemented by promoting remembrance of the past, organization of local cultural events and stimulating the activity of local creative organizations (Bąbska, Rymsza, 2014, pp. 28-29).

Recently, we have observed the renaissance of local communities followed by enhanced interest in regional issues by various groups, including sociologists, economists, culture scientists etc. We usually discuss the sense of belonging to a local community while referring to people who are directly linked to those communities. The local com- 
munity transforms space by giving it a specific name, structure and frequently a language. Physical properties of that space determine the nature of a community. The rural local community is considered to be a separate social and cultural entity that has changed under the influence of national and regional transformation. Until the mid $19^{\text {th }} \mathrm{c}$. in Poland, rural areas underwent changes adjusting them to the permanent cultural system. Long-term integration, aimed at engaging inhabitants of rural areas in various forms of activity, started in the second half of the $19^{\text {th }} \mathrm{c}$. While analyzing life and operation of the rural local community, it is important to collate its development with socio-economic changes in rural area in a given period. We may observe changes in the operation of economic mechanisms and mutual influence of rural areas, understood as a social entity, and larger systems. The first concept of a rural community, described in the Polish literature pertaining to the subject, was created by F. Znaniecki. He believed that: “...customs, laws and ideals of a group, fitted into an institutionalized system, such as family, local community, association, state etc., are the backbone of a social organization. Thus, such a group can be considered as a separate entity rather than a collection of individuals. Therefore, all norms, established by the group as binding principles, are secondary in terms of sociological significance" (Thomas, Znaniecki, 1976, p. 62).

A rural area can be defined through its functionalities with interrelated constituent parts. Thus, a local community is a dynamic entity. Its social grouping features result from internal forces of a rural community and its relations with their immediate environment. An important factor influencing the perception of rural areas is relatively low level of social infrastructure. Despite advancement made, its level is still lagging behind that of urban areas. Conditions for development of rural areas differ from region to region depending on its socio-economic situation. A rural local community suffers due to adverse phenomena that accompanied transformation in Poland. Those phenomena include unemployment (especially after collapse of state-owned agricultural enterprises - PGRs) and low profitability of agriculture. Frequently, rural areas are perceived as a place to live a monotonous life, and unprofitable and hard work. Some rural communities operate in socio-economically dilapidated areas previously occupied by large state-owned enterprises. Former employees of those enterprises have a sense of being neglected. They complain about the shortage of jobs, low income and lack of privileges previously offered by PGRs (e.g. free housing, additional sources of income) (Tarkowska, 2000). An area of a former PGR, with deteriorating buildings, reflect the marginalization of rural areas. Other components that add to the pessimistic picture include dilapidated manors and palaces, once used by PGRs as administration buildings, schools, pre-schools or possibly museums. However, attempts to restore their previous appearance and adapt to modern functions bode well for the future (e.g. Palaces in Wąsowo and Michorzewie, County of Nowy Tomyśl, Greater Poland Province, Poland). Despite all the above mentioned adversities, the contemporary rural area is highly appreciated in particular among young new inhabitants who consider it to be valuable due to the contact with nature. The contact with nature can be considered an added value despite poor aesthetics or the shortage of local infrastructure. The use of advantages related to the natural environment is paralleled with search for new opportunities to develop agriculture, such as ecological farming, popular agritourism and agrarian ecology based on natural and cultural heritage of rural areas. 


\section{Selected examples of citizen participation in rural local community}

The contemporary local community may resort to various forms of support and initiatives, e.g. "small projects" (funded from European Social Fund; max. project cost: EUR50 thou.). Target groups for the projects include: inhabitants of rural areas - rural and rural-urban municipalities and towns with population of up to 25 thousand; local communities active in integrating inhabitants of rural areas; entities operating in rural areas promoting active engagement of inhabitants. Those projects focus on the improvement of professional skills and integration and bottom up education initiatives implemented in rural areas. Those projects support the development of the local community in terms of desired social and economic changes, improvement of the quality of life in rural areas, among others, by boosting the activity of local communities and stimulating job creation.

Challenges faced by the rural local community include a citizen's passive attitude. In rural areas, the quality of life depends much on people themselves. The projects by developing human skills, interesting development of natural areas etc. may change the reality of the rural local community. In a community, participation involves primarily engagement of inhabitants in various activities designed to promote the development of the community by improving its resources and eliminating barriers. The lead goal is to promote participation of inhabitants in public life, support social communication and the development of the local community, and stimulation of local growth based on civic activity. Such community-based activity instills civic awareness and engagement. However, desired attitudes are not developed spontaneously. People and institutions need information and support, as well as education to be able to act for the benefit of their local communities. The development of the local community enriches individual and group contacts, tradition and behavior patterns, instilling self-esteem and strengthening the local community in its effort to improve the situation in respective rural areas. The overall objective is to promote development based on participation and inclusion of various ideas, views, experiences and rationale of less fortunate social groups. It is difficult to trigger local development mechanisms without the sense of responsibility for the common good and pro-active approach among inhabitants. We may ask the following question: How can we stimulate people so they can meet their own challenges and engage in the operation of their communities? Further in the article, I attempt to discuss selected examples of citizen participation in the rural local community.

A precondition of people's involvement in any action is their will to cooperate. There, a major role is played by leaders operating in those communities. They are actually responsible for organizing of the community to unleash the human potential instead of wasting in in futile activities. Other steps include setting goals and activities and establishing of the organizational structure and communication rules. It is also possible to establish a local partnership, which is a form of permanent cooperation involving various local entities. Such a cooperation is usually based on specific rules and mechanisms. The idea of partnership is very broad and encompasses a number of operational modes. A sample definition of partnership is the following: "A partnership means to include various levels of community and national authorities, as well as institutions and regional and local communities, which are familiar with actual needs and potential of the region, 
into processes of decision making and implementation. It is one of major principles underlying the implementation of structural funds" (European Social Fund). Although it is obvious that people should act together to support their community, difficulties they face (differences between sectors, divergent interests, domination of one partner, lack of skills to implement process, conflicts and personal issues) translate into reluctance among people to become engaged in such initiatives.

A social leader is a person who understands and recognizes needs of a given community, someone who, based on local community needs, is capable of building visions for change. Moreover, a leader should be capable of engaging others to make the change happen. A true leader is able to attract other people who will follow him/her. The leader puts group interests over individual ones. While engaging others, the leader listens to their ideas and opinions, and often goes beyond well-known paths to inspire others. A leader must be honest in his/her activity and use the language understood by the community.

For many years now, the EU has been supporting the development of rural areas and improvements regarding equal opportunities for the rural population. The Leader Initiative (Laisons Entre Action de Development de l'Economie Rural) plays an important role with respect of rural areas. The initiative was launched in 1991 to increase the development potential in rural areas based on local initiatives. It has been funded from EU structural funds. During 14 years, the EU has implemented three rounds of the programme: Leader I (1991-1993), Leader II (1994-1999), and Leader+ (2000-2006). Leader II was limited solely to rural areas with unutilized natural potential. Based on the previous experience, stage III expanded to cover all types of rural areas. At the moment, the Leader Programme is financed from the European Agricultural Fund for Rural Development (EAFRD). ${ }^{3}$ Leader is based on a bottom up partnership approach to the development of rural areas, which is implemented by Local Activity Groups (LAGs). A rural community need to develop their Local Development Strategy (LDS) and include innovative projects combining human, natural, cultural, historical and other resources. The primary goal is to build social capital in the rural area by involving all citizens and contributing to the creation of new jobs in rural areas. Local Activity Groups are partnerships consisting of representatives of three sectors: public, business, and society. Members of LAGs include individuals and NGOs, companies and entities, including bodies of the local government. The LAG Council, a decision-making body, should comprise social partners and economic partners (at least 50\%), in particular representatives of the civic society, such as farmers, women, and young people and their associations (Rozporządzenie Rady..., 2005).

Yet another excellent example of citizen participation at the level of rural local community are bottom up initiatives in the area of education. A contemporary rural area has

${ }^{3}$ Rural Development Programme 2014-2020 (RDP 2014-2020) is based on RU regulations, especially the Regulation of the European Parliament and the Council (EU) no 1305/2013 of 17 December 2013 on support for rural development by the European Agricultural Fund for Rural Development (EAFRD and repealing Council Regulation (EC) no. 1698/2005 and delegated and executive acts of the European Commission. According to the EU regulations, the Program is a component of the overall national development policy, in particular through the Partnership Agreement. The Agreement defines a strategy for using EU funding for the implementation of EU goals defined in the "Europe 2020 - Strategy for smart, sustainable and inclusive growth" taking into account development needs of a member state. 
become more open to changes and follows new technological trends. Unfortunately, the distance to the urban area is still considerable regarding cultural offer and education. A development policy for the development of rural areas needs to address both.

There are several definitions of a bottom up initiative. Other similar terms used include citizen, local, or social initiative. It can be discussed from various angles and each one of them is relevant. An initiative is nothing more than self-engagement, or a purposeful activity, aimed at meeting specific goals. It is also a response of the local community to a need or a problem that necessitates cooperation of a given community (e.g. supporting learning process among children and young people, language or computer courses, crafts workshops, organization of festival etc.). It can be compared with a social movement which is a form of a collective, spontaneous activity aimed at introducing changes to the local environment. Every initiative engages a specific group, sometimes the entire local community, facing a specific problem. The will to act together is present from the very beginning, then during the implementation of tasks and all the way until the accomplishment of a goal.

In terms of their themes, bottom up initiatives must fit into the scope defined by the Law of 24 April 2003 on public benefit and voluntary activity. According to the law, public benefit activity is "an activity producing specific benefits for the society and an activity implemented by non-governmental organizations in the area of public tasks defined by the law."

Bottom up initiatives result from needs of the local community and are expressed in the activity of the community, which was not imposed by any external body. Everyone can establish such an initiative. It is also possible that such initiatives are implemented by members of informal groups, associations and foundations.

An informal group can be established by at least three adult people willing to implement public benefit activities. Such a group does not have its legal personality. An informal group is a type of a social grouping of a fluid and flexible structure, strong personal links, no formal tasks, and informal social control, whereas a foundation is a non-governmental organization established to meet specific social or economic goals. It has its assets designated for the implementation of goals set by founding members. It is established by founders in the statement of will made in the form of a notary public deed (or testament). It can establish its legal personality once it is registered with the National Court Register (Ustawa $\mathrm{z}$ dnia 6 kwietnia $1984 \mathrm{r}$.). An association is created by a group of people (friends, acquaintances, colleagues, family members) having common needs and interests (e.g. music, art, sailing etc.) or a common goal (e.g. protection of cultural heritage) or a common interest (legal, artistic, health) (Ustawa z dnia 7 kwietnia 1989 r.).

A bottom up initiative, as any other project, needs to have efficient management. The initiative comprises a set of activities that need to be implemented to meet a preset goal. The initiative is a one of operation. Thus, repeatable actions cannot be referred to as initiatives.

A well-managed initiative must follow five steps. Step one involves the formulation of an idea or a vision, main goals of the initiative together with the arrangement of funding necessary to implement it, and qualified staff. Another important issue is the analysis of the environment and allocation of time for its implementation. Stage two covers the formation of the initiative group and appointment of its leader. At this stage, 
a schedule, budget, and the implementation deadlines are defined. It is also necessary to consider risks that may appear during the implementation phase. Another stage involves the performance of tasks according to the schedule while working towards goals of the initiative. The implementation of the initiative is based primarily on collaboration. Stage four is crucial since it includes the management of the initiative. A leader, a person responsible for the implementation of all stages, monitors the process of selecting contractors and controls the budget. The management process ends with a summary of all activities implemented. It requires a revision of all initiative goals and approval of their implementation. It is also necessary to draw conclusions that might be helpful for further initiatives (Kossek-Markowska, Kurcman, 2014, p. 14).

For instance, the purpose of bottom up education initiatives is to stimulate the rural local community to organize itself and develop actions promoting education and skills among inhabitants of rural areas. A bottom up initiative can be referred to as a social project designed to achieve specific results in a predetermined time.

Apart from education at school, a pre-school education is considered particularly important. It influences individual development of a child. The majority of skills are shaped in the pre-school period and determine intellectual and social development of a child. For this reason, access to pre-school education is of fundamental importance. In a rural area, not only does a pre-school educates, but also develops social competences, equalizes education opportunities, supports individual education needs, and at the same time provides a tremendous educational support for parents. Children in rural areas have restricted access to pre-school education. In recent years, initiatives have been implemented to mitigate the disparity. A number of projects have been implemented funded from EU structural funds. The collaboration of the Polish Civic Initiative Fund with regional partners led to the establishment of a number of pre-school facilities.

In rural areas, primary schools play the role of development centers, provide education, and organize cultural and sport events, and operate as venues for meetings. Since the number of public libraries decreased and public cafes closed (which operated during communist period), schools are frequently the only meeting venues for the local community. They organize language courses for rural local community, computer literacy courses for citizens or courses of fast reading and mnemotechniques for young people. According to E. Tołwińska-Królikowska (2011), a village school has always played other roles then its city counterpart. A village school has collaborated with its immediate environment, organizes local events and additional classes. This role is continued today, since village schools organize theme courses on cooking, enterprise, agritourism, and ecological farming.

Education and local tradition are promoted by reestablished Farmers' Wives Associations. They promote bread baking techniques, butter and cottage cheese manufacturing, embroidery and art paper cutting. Apart from the above mentioned activities, attention should be drawn to initiatives implemented by the Voluntary Fire Fighting Service, Senior Citizen Clubs and Local Sport Clubs. They organize meetings and lectures on first aid, occasional events (harvest and bread festivals etc.), sport activities (aerobics, football, Nordic walking, biking tours). In cooperation with local authorities (village leaders and village councils), they invite organizations promoting the development of rural areas to examine various opinions and benefit from their experience. 


\section{References}

Bąbska B., Rymsza M., Organizowanie lokalnej społeczności - metodyka pracy środowiskowej, Centrum Wspierania Aktywności Lokalnej CAL, Warsaw.

Brodie E., Cowling E., Nissen N., Ellis Paine A., Jochum V., Warburton D. (2009), Understanding participation: A literature review, National Council for Voluntary Organisations, London.

Creighton J. L. (2005), The Public Participation Handbook, Jossey-Bass, San Francisco.

Elliott J., Heesterbeek S., Lukensmeyer C. J., Slocum N. (2005), Participatory Methods Toolkit. A practitioners manual, King Baudouin Foundation.

Europejski Fundusz Społeczny, https://www.funduszeeuropejskie.gov.pl/efs/.

IAP2 Spectrum of Public Participation, International Association for Public Participation (IAP2), https://www.iap2.org.au/Tenant/C0000004/00000001/files/IAP2_Public_Participation_Spectrum.pdf, 23 March 2019.

Idziak W. (1990), Biznes, Koszalińskie Wydawnictwo Prasowe, Koszalin.

Kaźmierczak T. (2011), Partycypacja publiczna: pojęcie, ramy teoretyczne, in: Partycypacja publiczna: o uczestnictwie obywateli w życiu wspólnoty lokalnej, ed. A. Olech, Warszawa.

Komito L. (2005), e-Participation and Governance: Widening the Net, "The electronic journal of e-Government", no. 1.

Kossek-Markowska K., Kurcman D. (2004), Od inspiracji do realizacji, czyli słów kilka o inicjatywach oddolnych, Kielce.

Lewenstein B. (2006), Nowy paradygmat rozwoju układów lokalnych - w stronę obywatelskich wizji społeczności lokalnych, IFiS PAN, Warszawa.

Program Rozwoju Obszarów Wiejskich 2014-2020 (PROW 2014-2020), rozporządzenie Rady (WE) nr 1698/2005 z dnia 20 września 2005 r. w sprawie wsparcia rozwoju obszarów wiejskich przez Europejski Fundusz Rolny na rzecz Rozwoju Obszarów Wiejskich (EFRROW), (Dz. Urz. UE L 277/1)

Roberts N. C. (2008), Direct Citizen Participation: Challenges and Dillemas, in: The Age of Direct Citizen Participation, eds. N. C. Roberts, M. E. Sharp, Armonk-New York

Starosta P. (1995), Poza metropolia. Wiejskie i małomiasteczkowe zbiorowości lokalne a wzory porzadku makrospołecznego, Wydawnictwo Uniwersytetu Łódzkiego, Łódź.

Tarkowska E. (2000), Bieda popegeerowska, in: Zrozumieć biednego. O dawnej i obecnej biedzie $w$ Polsce, ed. E. Tarkowskiej, Warszawa.

Thomas W. I., Znaniecki F. (1976), Chłop polski w Europie i Ameryce, Warsaw.

Tołwińska-Królikowska E. (2011), Mała wiejska szkoła podstawowa - niezbędny ośrodek rozwoju społeczności lokalnej.

Ustawa z dnia 7 kwietnia 1989 r. Prawo o stowarzyszeniach, Dz. U. 1989, Nr 20, poz. 104.

Ustawa z dnia 6 kwietnia 1984 r. o fundacjach, Dz. U. 1984, Nr 21, poz. 97.

Ustawa z dnia 24 kwietnia 2003 r. o dziatalności pożytku publicznego i o wolontariacie, Dz. U. 2003, Nr 96, poz. 873.

\section{Partycypacja obywatelska na poziomie wiejskich społeczności lokalnych - próba analizy zagadnienia}

\section{Streszczenie}

Partycypacja obywatelska jest istotnym elementem współczesnej demokracji. Traktowana jest jako ratunek wobec stałego obniżania udziału obywateli w życiu politycznym i publicznym. Partycypację 
można podejmować z bardzo rożnych powodów. Istotne jest to, iż sprzyja ona rozwojowi demokracji lokalnej, chociażby poprzez wzmocnienie oddolnych inicjatyw obywatelskich; pobudza integracje środowisk lokalnych dzięki podejmowaniu wspólnych działań. Jest również skutecznym sposobem na rozwiązanie problemów: daje możliwość wysłuchania opinii wszystkich zainteresowanych osób, rozwiązania lokalnych konfliktów i wypracowania kompromisu.

W niniejszym tekście podjęto próbę przeanalizowania zagadnienia partycypacji obywatelskiej na przykładzie konkretnej grupy społecznej, jaką jest wiejska społeczność lokalna. Skoncentrowano się na różnych teoretycznych ujęciach tych dwóch zagadnień. Celem tekstu jest przede wszystkim odpowiedź na pytanie o formy zaangażowania wiejskich społeczności lokalnych w działania partycypacyjne; ukazanie przykładowych instrumentów, które umożliwiają członkom tej wspólnoty uzewnętrznienie ich aktywności i postaw obywatelskich.

Słowa kluczowe: partycypacja obywatelska, aktywność publiczna obywateli, społeczność lokalna 
